pp. $39-51$

\author{
Patrycja ŚWISTAK
}

ORCID: 0000-0003-3873-2912

Uniwersytet Pedagogiczny im. KEN w Krakowie

\title{
Edukacja wczesnoszkolna w trybie stacjonarnym i zdalnym a motywacja ucznia $z$ perspektywy rodzica
}

\begin{abstract}
Early School Education in Stationary and Remote Modes and the Student's Motivation from the Parent's Perspective

Over the past few months, due to the pandemic situation, students, parents, and teachers have faced the challenge of having to take classes remotely. The unstable reality has caused early childhood education to alternate between on-site and remote modes. This paper addresses the issue of motivation among early elementary school children in the era of pandemic and remote education. The paper includes characteristics of the early childhood period, education at this developmental stage, remote education, and an introduction to the topic of motivation. An inclusive survey of 50 parents was conducted to find out their opinions on motivation in relation to learning and other activities of their children who are in the younger school age. The results are included in the paper.
\end{abstract}

Keywords: motivation, early school education, early school age, distance education, e-learning, integrated learning.

Słowa kluczowe: motywacja, edukacja wczesnoszkolna, wiek wczesnoszkolny, edukacja zdalna, e-learning, kształcenie zintegrowane

\section{Wiek wczesnoszkolny — wprowadzenie}

Wczesny wiek szkolny, późne dzieciństwo, młodszy wiek szkolny — to określenia dotyczące okresu rozpoczynającego się na przełomie szóstego i siódmego roku życia i trwającego do dziesiątego-dwunastego roku życia (Bee, 2004, s. 263; Stefańska-Klar, 2000, s. 130). W życiu dziecka zachodzą istotne zmiany, szczególnie uwidaczniające się w codziennej aktywności oraz zdobywaniu nowych ról i umiejętności. Swobodna i beztroska zabawa, która do osiągnięcia młodszego wieku szkolnego stanowiła główną działalność dziecka, zaczyna 
stopniowo zanikać, a jej miejsce zastępuje konieczność wypełniania zadań, obowiązków, uczenia się, przystosowywania się do nowych sytuacji. Przejście z okresu przedszkolnego wiąże się ze zmianami dotyczącymi znaczenia osób istotnych w życiu dziecka. Rodzice, którzy dotychczas stanowili bezpieczne oparcie i niekwestionowany autorytet, nie pozostają jedynym źródłem wywierania wpływu, a stają się jednym ze źródeł. Dziecko, przyjmując nową rolę społeczną - ucznia, wchodzi w świat szkoły, gdzie spotyka nowych, nieznanych dotąd ludzi. Poszerza się zatem najbliższe środowisko dziecka - pojawiają się rówieśnicy, nauczyciele, stanowiący istotny punkt odniesienia dla wszelkich działań (Stefańska-Klar, 2000, s. 130). Zdaniem Erika Eriksona (1997) ten etap w życiu człowieka charakteryzuje jeden z ośmiu kryzysów rozwojowych, który cechuje pracowitość i poczucie niższości. Przez zdobywanie sukcesów w działaniach charakterystycznych dla wieku dziecka kształtuje się u niego poczucie fachowości i radzenia sobie $\mathrm{z}$ wymaganiami otoczenia. Brak powodzenia $\mathrm{w}$ podejmowanych aktywnościach w konsekwencji może $\mathrm{z}$ kolei prowadzić do obniżonego poczucia własnej wartości (Stefańska-Klar, 2000, s. 133). W porównaniu ze wcześniejszym etapem rozwojowym - okresem przedszkolnym - pojawiają się zmiany na płaszczyźnie komunikacyjnej, poznawczej, moralnej.

Rozwój poznawczy dziecka w okresie wczesnoszkolnym charakteryzuje osiąganie zdolności rozwiązywania problemów oraz wyobrażania sobie przedmiotów i operowania nimi w myślach bez bezpośredniego kontaktu. Uczeń potrzebuje rzeczywistych materiałów, które ułatwią mu zrozumienie treści i funkcjonowanie w środowisku szkolnym, dlatego zadaniem szkoły jest stwarzanie przyjaznych warunków dla jego rozwoju (Adamek, 1997, s. 170). W tym okresie człowiek kształtuje umiejętność wypowiadania się na różne tematy, dyskutowania, dostrzegania fałszu, braku logiki oraz związków przyczynowo-skutkowych. Dotychczas (w wieku przedszkolnym) dziecko przejawiało egocentryczną postawę, w późniejszym okresie osiąga natomiast decentrację poznawczą, to znaczy umiejętność obiektywnego ujmowania rzeczywistości, przyjęcia odmiennego punktu widzenia (Stefańska-Klar, 2000, s. 136).

Zmiany uwidaczniają się także w sferze moralności dziecka. Rozwój tego obszaru przebiega w kilku etapach. Zdaniem Jeana Piageta (za: Stefańska-Klar, 2000, s. 136-137) początek okresu późnego dzieciństwa cechuje stadium realizmu moralnego. Jeżeli dziecko zauważa pewne reguły społeczne, traktuje je jako najważniejsze i bezdyskusyjne - takie zjawisko nazywa się moralnością heteronomiczną, która powoduje przekonanie, że każdorazowe naruszenie musi skutkować ukaraniem. Dopiero w stadium moralnego relatywizmu dziecko uświadamia sobie, że reguły nie muszą być stałe, a ich naruszanie w określonych przypadkach może być dopuszczalne. Pod koniec okresu późnego dzieciństwa zauważa się u dziecka moralność autonomiczną, która przejawia się w postępowaniu w taki sposób, jaki samo dziecko uważa za właściwy. 
Irena Adamek (1997, s. 178) wiek wczesnoszkolny określa również mianem wieku: świata;

— rozumu, z uwagi na przyswajalność nowych informacji, poznawania

— pa mi ię ci, ponieważ szczególnie w tym okresie uwidaczniają się u dziecka możliwości zapamiętywania;

- społecznego, przejawiającego się w nawiązywaniu relacji rówieśniczych, funkcjonowaniu w nowym środowisku szkolnym;

- aktywności, czyli zdolności do zaangażowania się we własne działania;

- ekspansji, ze względu na wyrażanie własnych emocji w różnych formach oraz twórczość przejawiającą się m.in. w rysunku, zabawie, tańcu, śpiewie.

\section{Specyfika edukacji wczesnoszkolnej}

Młodszy wiek szkolny to czas wielu zmian i spełniania nowych zadań rozwojowych. Ważną zmianę stanowi podjęcie edukacji szkolnej i wejście w rolę ucznia. Wkraczając $\mathrm{w}$ środowisko szkolne i chcąc poradzić sobie $\mathrm{z}$ nowymi wymaganiami, dziecko musi osiągnąć dojrzałość szkolną, która przejawia się w kilku aspektach. Aby mówić o dojrzałości szkolnej u dziecka, istotny jest prawidłowy rozwój fizyczny i ruchowy, szczególnie w zakresie motoryki małej. Zdobywanie wiedzy $\mathrm{w}$ warunkach szkolnych powinno być poprzedzone wyposażeniem dziecka w wiedzę podstawową, ogólną — o sobie, świecie i otoczeniu. Gotowość sprostania wymaganiom szkoły nie jest możliwa bez podstawowych umiejętności komunikacyjnych, które ułatwią uczniowi porozumiewanie się zarówno z osobami starszymi, jak i z rówieśnikami. Co więcej, o dojrzałości szkolnej decyduje umiejętność współdziałania, wykonywania poleceń nauczyciela oraz radzenia sobie $\mathrm{z}$ emocjami i rozstaniem $\mathrm{z}$ osobami bliskimi na czas trwania lekcji (Stefańska-Klar, 2000, s. 131).

W okresie edukacji wczesnoszkolnej życie dziecka ulega przeobrażeniu. Oprócz zmian obejmujących dotychczasowe aktywności jest to czas, kiedy uczeń musi opanować podstawowe umiejętności kluczowe w kontekście dalszej nauki, rozwoju i późniejszych etapów życia. Do tej grupy zaliczyć należy: naukę pisania, czytania oraz podstaw matematyki, co wymaga motywacji zarówno ze strony dziecka, jak i jego nauczycieli oraz rodziców (Murawska, 2014, s. 5). Edukacja wczesnoszkolna stanowi podstawę kolejnych etapów nauki szkolnej i w znacznym stopniu determinuje przyszłość dziecka. W tym procesie ogromną rolę przypisuje się nauczycielom, wychowawcom, których zadaniem jest nie tylko opieka, ale również przekazywanie wiedzy i kształtowanie nowych umiejętności przy zastosowaniu elementów zabawy (Adamek, 1997, s. 167). 
Barbara Murawska edukacją wczesnoszkolną nazywa „stopniowe przechodzenie od nauki okazjonalnej do świadomego uczenia się — pod kierunkiem innej osoby, w jej obecności, a gdy trzeba - pomocy" (2014, s. 5). Zdaniem autorki podstawowy warunek zaistnienia tego procesu stanowi właściwe środowisko edukacyjne, stwarzające warunki rozwoju i rozwiązywania problemów oraz powodujące zaciekawienie dziecka i motywację do podejmowania działań. Zgodnie z Rozporządzeniem Ministra Edukacji Narodowej z dnia 14 lutego 2017 r. edukacja wczesnoszkolna obejmuje klasy I-III. Dokument wskazuje cele, do jakich powinna dążyć edukacja na tym etapie. Główną intencją jest wspieranie rozwoju dziecka i zaspokojenie jego potrzeb rozwojowych oraz zapewnienie mu warunków wspomagających osiąganie dojrzałości koniecznej w dalszych etapach edukacyjnych. Realizację wymienionych dążeń szkoła może uzyskać przez wypełnianie odpowiednich zadań. Rozporządzenie określa wiele poleceń zorientowanych na: wspieranie aktywności i rozwoju dziecka, organizowanie prawidłowych warunków rozwoju i nauki (w tym również programu nauczania, odpoczynku, zabawy), współpracę z rodzicami i kluczowymi instytucjami oraz dobór zajęć dostosowanych do indywidualnych potrzeb i możliwości uczniów.

$\mathrm{Z}$ edukacją wczesnoszkolną wiąże się pojęcie kształcenia zintegrowanego. Termin odnosi się do takiego nauczania, które zakłada łączenie wiedzy zdobywanej w środowisku szkolnym z własnymi doświadczeniami ucznia (Murawska, 2014, s. 11). Lekcje powinny opierać się nie tylko na tradycyjnym przekazywaniu informacji, ale - przy zastosowaniu różnorodnych metod atrakcyjnych dla dziecka - także na uczeniu się rozwiązywania sytuacji problemowych i wykorzystaniu zdobytej wiedzy w praktyce. Istotę kształcenia zintegrowanego stanowi zatem spajanie wiedzy dotyczącej różnych obszarów życia przy stosowaniu różnorodnych środków, metod, form (Sendecka, 2017, s. 6). Kształcenie zintegrowane nie tylko umożliwia łączenie własnych zasobów wiedzy $\mathrm{z}$ informacjami zdobywanymi w szkole, ale także — jeżeli przyjmuje właściwą formę i uczeń nie jest tylko biernym słuchaczem nauczyciela — sprzyja rozwojowi samodzielności u dziecka, podejmowaniu aktywności poznawczej, doświadczaniu i poszerzaniu umiejętności społecznych (Murawska, 2014, s. 12). Istnieje jednak zagrożenie, iż nauczyciel nie zrozumie właściwego sensu i założeń wynikających z kształcenia zintegrowanego, co może skutkować m.in. nieodpowiednim tworzeniem programu nauczania i projektowaniem własnych działań.

\section{Edukacja zdalna w dobie pandemii}

W czasach pandemii nauczanie zdalne stanowi główną formę edukacji i $\mathrm{w}$ dużej mierze - substytut nauczania stacjonarnego w szkole. 
Czynnikami decydującymi o sukcesie edukacji zdalnej są przede wszystkim zasoby edukacyjne (dostępne $\mathrm{w}$ internecie), zasoby techniczne, czyli przede wszystkim sprawny sprzęt oraz odpowiednie łącze internetowe, a także umiejętność nauczycieli planowania i przygotowywania zdalnych lekcji. $Z$ podanych trzech elementów najważniejszym i jednocześnie najtrudniejszym do osiągnięcia jest ostatni. Podstawowym celem w organizacji zajęć powinno stać się zaciekawienie ucznia i pobudzenie jego motywacji do zagłębiania się w tematykę lekcji oraz rozwiązywania problemów wspólnie z nauczycielami i rówieśnikami. Istotna jest przy tym znajomość możliwości, jakie oferuje nam nowoczesna technologia, oraz umiejętność wykorzystania różnych narzędzi w kontekście aktywizacji ucznia, organizowania pracy w grupach, przekazywania wiedzy, konstruowania zadań i ich oceny (Koludo, 2020, s. 43-50).

Natalia Walter (2020) zwraca uwagę na znaczenie dostosowania sposobu pracy do każdej grupy wiekowej odrębnie. Autorka uważa, że dzieci w młodszym wieku szkolnym są kreatywne i gotowe stawiać czoła wyzwaniom. Motywacja, zarówno wewnętrzna, jak i zewnętrzna, w tym wieku odgrywa istotną rolę w osiąganiu sukcesów edukacyjnych. Dzięki tej wiedzy nauczyciel ma podstawę do projektowania zdalnych lekcji i doboru odpowiednich platform e-learningowych. Przy edukacji na odległość szczególne ważną rolę odgrywają rodzice. Nauczyciele, choć nie pozostają z uczniami w bezpośrednim kontakcie, są zobowiązani nie tylko do zorganizowania lekcji, ale również do dbałości o własną prezencję podczas nich. Dla młodszych odbiorców szczególnie ważny jest kontakt z nauczycielem, a więc powinien on dostosować ubiór, gestykulację oraz sposób mówienia tak, by pobudzić motywację i zainteresowanie ucznia. Ponadto, biorąc pod uwagę charakterystykę wieku wczesnoszkolnego, należy uwzględniać u dziecka potrzebę zabawy i korzystać $\mathrm{z}$ różnych interaktywnych rozwiązań łączących zabawę z nauką, np. gry edukacyjne (s. 53-55).

$\mathrm{Z}$ nauczaniem zdalnym wiąże się pojęcie e-learningu, który definiuje się jako alternatywną postać nauczania, stosowaną w wielu dziedzinach życia, przy użyciu nowoczesnych technologii, za pomocą narzędzi, jakimi są m.in. portale czy platformy (Plebańska, 2011, s. 9-11). Jest to pojęcie szerokie, różnie rozumiane (Woźniak, 2009, s. 33). Cechą wspólną wielu definicji jest korzystanie z sieci oraz brak bezpośredniego kontaktu z nauczycielem. Korzystając z e-learningu, człowiek uczy się organizować własny czas. Kształcenie na odległość często stwarza możliwość wyboru czasu i miejsca, w którym ma się odbywać nauka, a także daje poczucie zwiększenia się wolnego czasu $\mathrm{w}$ zamian za przygotowywanie się, wychodzenie i przebywanie w szkole. Zmusza do większej samodzielności i zaangażowania oraz odpowiedzialności za własną naukę, co wynika z braku obecności nauczyciela.

Nauczanie zdalne odbiera jednak wiele możliwości. Jednym $z$ istotniejszych aspektów, których nie zapewnia, są bezpośrednie spotkania z nauczycielami, ró- 
wieśnikami, swobodne rozmowy, wymiany zdań. Motywowanie i aktywizowanie uczniów jest w tym wypadku trudniejsze niż podczas nauczania w szkole. Ograniczenie może stanowić również brak dostatecznej znajomości obsługi komputera, poruszania się na platformach e-learningowych itp. (Grabania, Ślusarczyk, 2017, s. 36).

\section{Problematyka motywacji}

Motywację definiuje się jako „proces inicjowania, kierowania i podtrzymywania aktywności fizycznych i psychicznych, obejmujący mechanizmy wyboru określonego działania spośród innych oraz energię i wytrwałość reagowania" (Gerrig, Zimbardo, 2012, s. 468). To pojęcie jest punktem zainteresowań psychologów, ponieważ motywacja stanowi jeden $\mathrm{z}$ tych wewnętrznych napędów, które decydują o zachowaniach człowieka. Jest ona abstrakcyjna i nieobserwowalna w odróżnieniu od zdeterminowanych przez nią zachowań (Zimbardo, 1999, s. 436). Wskazuje się na dwa typy motywacji. Źródła motywacji wewnętrznej tkwią w samym człowieku - oznacza to, iż podejmuje on daną aktywność bez względu na zewnętrzne impulsy. Gdy natomiast podstawę motywowania się do wykonania określonych czynności stanowią kary i nagrody, wtedy mówić można o motywacji zewnętrznej (Zimbardo i in., 2017, s. 7). Porównując motywację wewnętrzną i zewnętrzną, uznać można, iż bardziej istotna jest ta pierwsza. Stosowanie w celu zachęcenia do działania wyłącznie wzmocnień jest niekorzystne z dwóch przyczyn: po pierwsze, powoduje zanikanie motywacji wewnętrznej i wytrwałości w dążeniu do celów; po drugie, sprawi, że człowiek, koncentrując się wyłącznie na osiąganiu nagrody lub uniknięciu kary, nie doświadczy pełnego zadowolenia z własnych działań (Kordziński, 2007, s. 11$-12)$.

Poruszając problem motywacji, warto odnieść się do kluczowych teorii wyjaśniających omawiane zagadnienie. Zgodnie z założeniem pierwszej - teorii instynktów - to właśnie one stanowią podłoże ludzkich zachowań. Koncepcja ta opiera się na przekonaniu, iż człowiek, podobnie jak zwierzęta, ma instynkty napędzające go do działania. W początkowej wersji przedstawiciele tego stanowiska przypisywali instynktom nie tylko inicjowanie pewnych zachowań, ale także odpowiedzialność za ich kierunek oraz wytrwałość. Wraz z upływem czasu uznano znaczenie uczenia się i struktur poznawczych człowieka. Ponadto obecnie odchodzi się od stosowania terminu „instynkt”, wskazującego na wrodzony charakter źródeł zachowań, na rzecz „uwarunkowań biologicznych/genetycznych" (Franken, 2005, s. 26-27).

Abraham Maslow, opracowując hierarchię potrzeb życiowych człowieka (potrzeby fizjologiczne, bezpieczeństwa, przynależności, szacunku, poznawcze, es- 
tetyczne, samorealizacji, transcendencji) (Zimbardo, 1999, s. 444), wskazał na ich znaczenie dla motywacji. Zaspokojenie potrzeb niższego rzędu zwiększa wartość potrzeb wyższych i aktywuje motywację do ich realizowania. Motywacja wynika zatem z potrzeb - zaspokojenie jednych pobudza motywację do zaspokajania kolejnych. Zdaniem Maslowa wyróżnia się tzw. motywację braku, która oznacza dążenie organizmu do osiągnięcia równowagi, oraz motywację wzrostu, kiedy człowiek chce osiągać cele wyższego rzędu (s. 444-445).

Teoria społecznego uczenia się upatruje źródeł motywacji w czynnikach zewnętrznych. Człowiek, obserwując zachowania modela, zdobywa wiedzę na temat o tym, jakie czynności są nagradzane, a jakie karane. Dzięki temu potrafi on zaplanować przebieg swoich dążeń, unikając komplikacji. Informacje płynące ze środowiska stanowią podstawę motywacji do podejmowania pewnych działań (Franken, 2005, s. 37).

Wedle teorii rozwoju i doskonalenia się zachowania człowieka są motywowane przez chęć utrzymywania pozytywnych kontaktów ze środowiskiem. W związku z tym jednostka doskonali się, by sprostać oczekiwaniom innych. Istnienie różnicy między tym, $w$ jakim miejscu obecnie się znajduje, i do jakiego dąży, oraz pojawiający się przy tym negatywny stan emocjonalny pobudzają motywację do podejmowania odpowiednich działań (Franken, 2005, s. 39).

Carl Rogers, jeden z czołowych reprezentantów podejścia humanistycznego, uważał, że człowiek wyposażony jest we wrodzoną skłonność dążenia do samorealizacji. Co więcej, jego zdaniem jednostka dysponuje umiejętnością oceny, które zachowania sprzyjają, a jakie blokują drogę do tego celu. Motywację do pełnienia określonych czynów powinny stanowić wewnętrzne pobudki, własna ocena tego, co jest dobre dla samego człowieka - kierowanie się wyłącznie aprobatą innych ludzi stanowi zagrożenie dla jego rozwoju (Franken, 2005, s. 41).

Przedstawiciele teorii poznawczej, w odróżnieniu od wymienionych koncepcji, definiują motywację jako „subiektywną interpretację optymalnych warunków” (Zimbardo, 1999, s. 445). Teoria nie uwzględnia znaczenia czynników biologicznych, genetycznych czy wewnętrznych, jako czegoś, co sprzyja motywacji, a większe znaczenie przypisuje bodźcom płynącym z otoczenia (s. 446).

\section{Motywacja do nauki - badania własne}

Na potrzeby niniejszego artykułu przeprowadzono badanie za pomocą kwestionariusza ankiety. Narzędzie zostało opracowane przy użyciu platformy Google Forms i rozesłane metodą kuli śnieżnej. Badanie zostało skierowane do rodziców dzieci w wieku wczesnoszkolnym. Respondentów powiadomiomo o anonimowości i dobrowolności udziału w badaniach; ankiety wypełniło 50 rodziców 


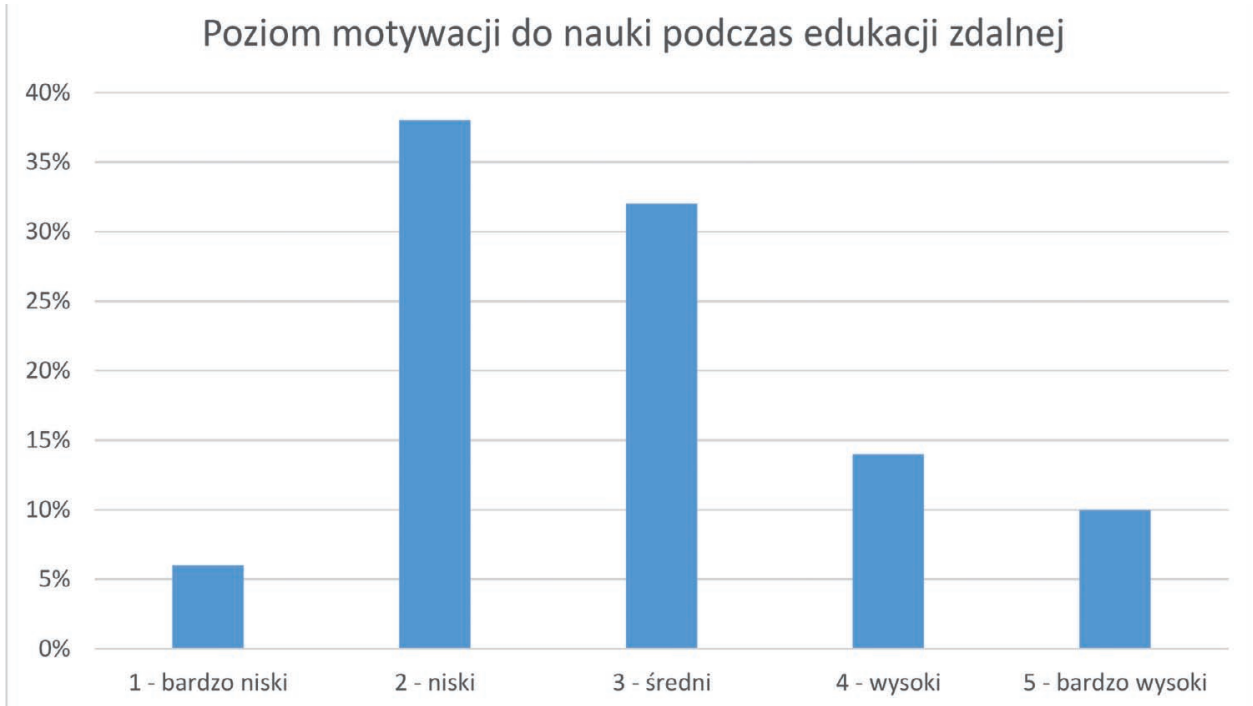

Wykres 1. Opracowanie własne

dzieci klas I-III. Głównym celem badania było zapoznanie się z opiniami rodziców na temat motywacji ich dzieci w kontekście edukacji zdalnej oraz stacjonarnej. Problemy badawcze zostały sformułowane w następujących pytania: Czy sytuacja pandemiczna wpływa na poziom motywacji dziecka? Jakie czynniki mogą powodować wysoki poziom motywacji do nauki zarówno w trakcie edukacji zdalnej, jak i stacjonarnej? W stosunku do jakich czynności motywacja dziecka jest wysoka? Jaki stosunek oraz poziom zaangażowania przejawiają dzieci wobec nauki w trybie zdalnym, a jaki w stacjonarnym?

W ocenie rodziców dzieci w wieku wczesnoszkolnym są bardziej pozytywnie nastawione do uczestnictwa w lekcji w trybie stacjonarnym niż zdalnym, co zadeklarowało $74 \%$ osób. Odmienne zdanie wyraziło $14 \%$ respondentów, sugerując, iż ich dzieci preferują uczestnictwo w lekcjach niestacjonarnych, $12 \%$ zauważa natomiast stosunek obojętny. Na pytanie: „Czy uważa Pani/Pan, że motywacja Pani/Pana dziecka do podejmowania nauki uległa zmianie $z$ powodu pandemii?" $60 \%$ badanych rodziców odpowiedziało, że sytuacja pandemiczna wpłynęła negatywnie na poziom motywacji ich dzieci. Zaledwie $4 \%$ respondentów dostrzegło pozytywne zmiany w tym zakresie, $36 \%$ natomiast nie zauważyło zmian w motywacji dziecka spowodowanych pandemią.

W celu porównania poziomu motywacji w trakcie edukacji zdalnej i stacjonarnej wśród dzieci w okresie późnego dzieciństwa zadano rodzicom dwa odrębne pytania. Pierwsze $z$ nich dotyczyło oceny poziomu motywacji podczas edukacji w trybie zdalnym, a następne w trybie stacjonarnym. Zastosowano ska- 


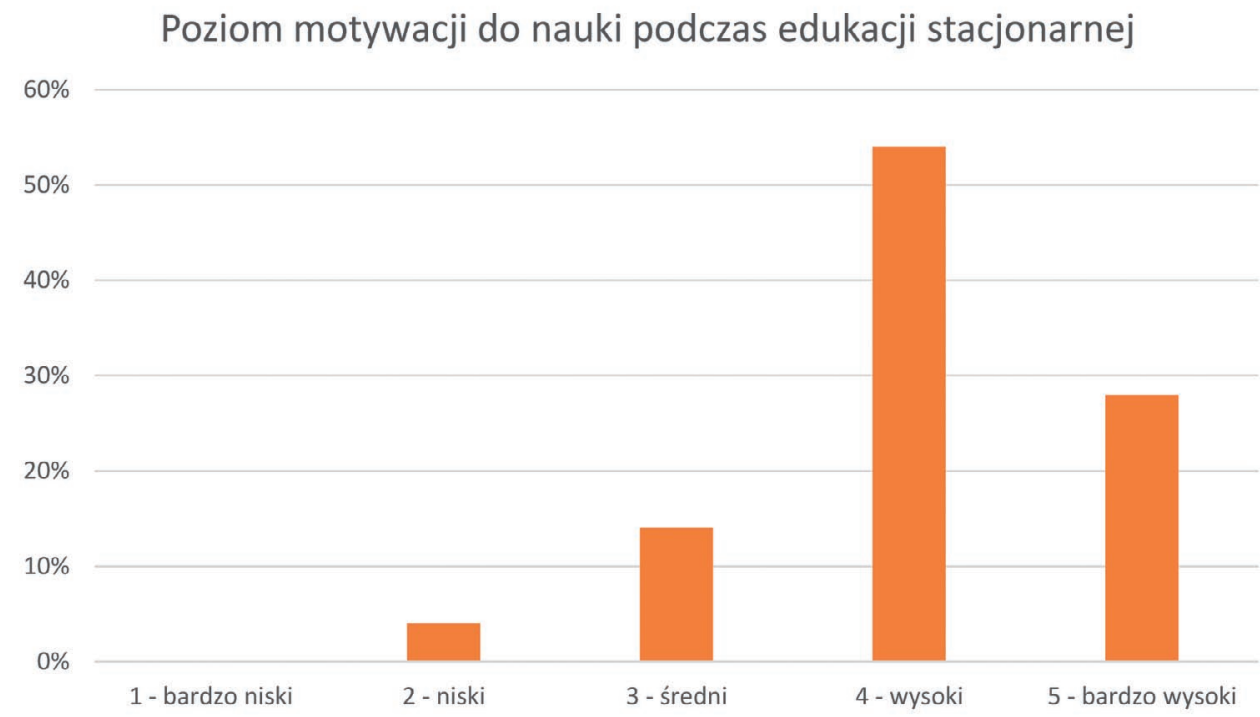

Wykres 2. Opracowanie własne

lę od 1 do 5, przy czym: ocena 1 oznaczała „bardzo niski”, 2 - „niski”, 3 „średni”, 4 - „wysoki”, 5 — „bardzo wysoki”. Wyniki zostały zamieszczone na poniższych wykresach.

Przeważający odsetek respondentów ocenia poziom motywacji dzieci do nauki w trakcie edukacji zdalnej jako niski (38\%) lub średni (32\%); 14\% osób badanych określiło ten poziom jako wysoki, a $10 \%$ — jako bardzo wysoki. Najmniej osób (6\%) zaznaczyło odpowiedź „bardzo niski”. W odniesieniu do edukacji stacjonarnej większość badanych osób stopień motywacji do nauki swoich dzieci ocenia jako wysoki (54\%) lub bardzo wysoki (28\%). W stosunku do edukacji zdalnej niższy odsetek respondentów (14\%) deklaruje poziom motywacji jako średni. Odpowiedź „niski” została wybrana przez 4\% osób, nikt nie zaznaczył natomiast opcji „bardzo niski”. Na podstawie powyższych danych można zatem stwierdzić, iż poziom motywacji dzieci do nauki jest znacznie niższy w trakcie edukacji zdalnej niż stacjonarnej. Respondentów poproszono również o określenie częstotliwości i stopnia zaangażowania w przygotowywanie się do lekcji zdalnych i stacjonarnych, m.in. przez odrabianie zadań domowych, samodzielne poszukiwanie materiałów. 50\% ankietowanych nie zauważa różnicy między stopniem przygotowywania się do lekcji zdalnych a stacjonarnych. Zdaniem $48 \%$ osób badanych ich dzieci poświęcają więcej czasu i zapału na przygotowywanie się do lekcji stacjonarnych niż zdalnych. Zaledwie $2 \%$ ankietowanych wskazało na tendencję odwrotną. 


\section{Motywacja do innych aktywności na podstawie wyników badań}

Zagadnienie motywacji dotyczy nie tylko kwestii edukacji, ale również innych sfer życia. W części teoretycznej zaprezentowano czynności charakterystyczne dla tego wieku, są nimi m.in.: spotkania z rówieśnikami, czytanie, pisanie, zabawa, rozwój zainteresowań. Kwestionariusz zawierał pytania, na których podstawie możliwe było dokonanie porównania poziomu motywacji w okresie edukacji zdalnej i stacjonarnej wobec konkretnych aktywności zaproponowanych w kwestionariuszu.

Na podstawie powyższych danych można wnioskować, iż edukacja w trybie zdalnym nie sprzyja pobudzaniu motywacji do podejmowania innych aktywności niż nauka. Wyniki badania wskazują na różnice w poziomie motywacji $\mathrm{w}$ odniesieniu do konkretnych sfer działania dziecka. Zestawienie sugeruje, iż stopień zmotywowania wobec każdej z wymienionych czynności jest wyższy w okresie, w którym edukacja odbywa się w trybie stacjonarnym. Dane zamieszczone zarówno na wykresie 3, jak i 4, wykazują, że wśród dzieci w wieku wczesnoszkolnym rodzice zauważają największy poziom motywacji wobec czynności takich jak zabawa i spotkania z rówieśnikami. Aktywności, w stosunku do których najczęściej dzieci przejawiają bardzo niski, niski lub średni poziom zmotywowania, to: dobrowolne podejmowanie czytania, pisania oraz rozwiązywanie łamigłówek, przy czym więcej takich odpowiedzi udzielono na pytanie odnoszące się do edukacji w trybie zdalnym.

\section{Poziom motywacji dzieci w stosunku do poniższych aktywności w trakcie edukacji stacjonarnej}

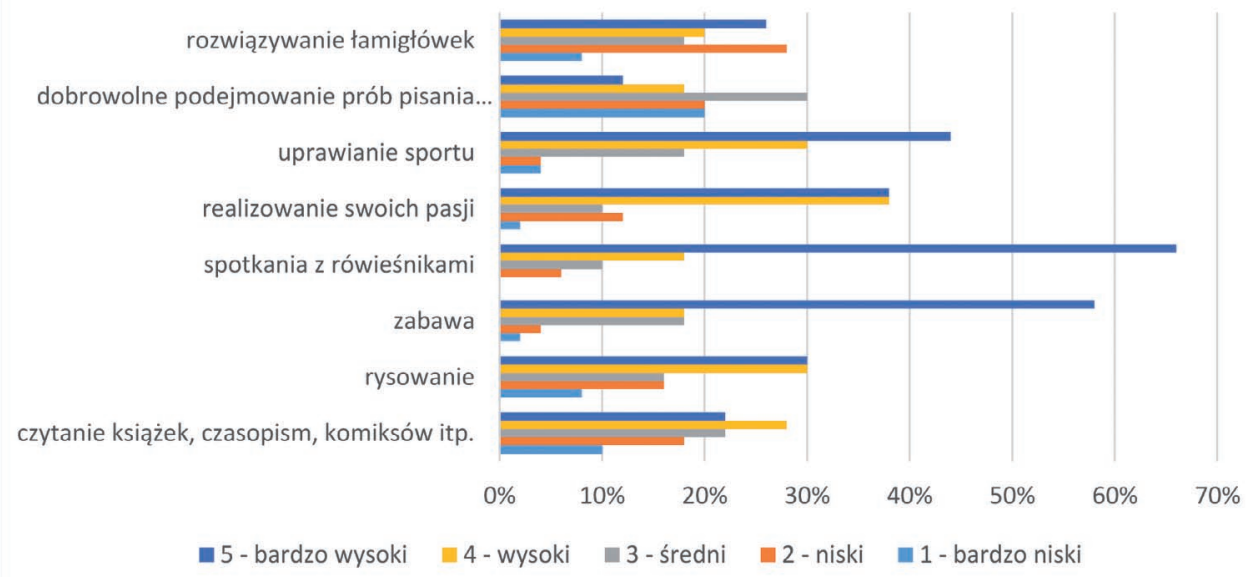

Wykres 3. Opracowanie własne 


\section{Poziom motywacji dzieci w stosunku do poniższych aktywności w trakcie edukacji zdalnej}

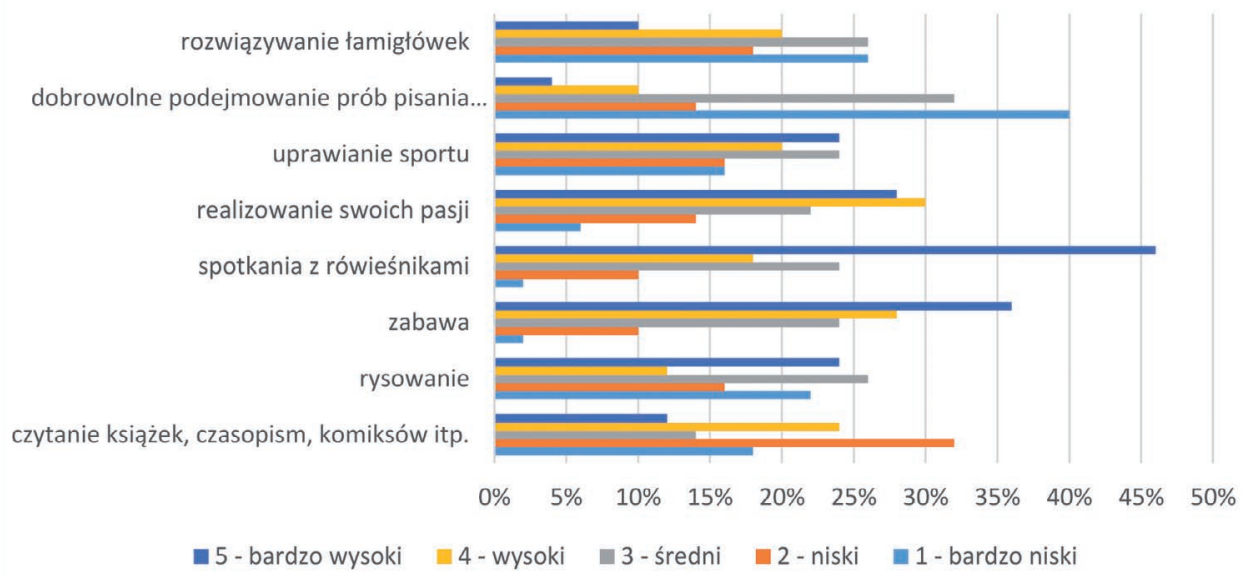

Wykres 4. Opracowanie własne

\section{Czynniki wpływające na wysoki poziom motywacji}

Zapytano ankietowanych rodziców o to, jakie czynniki spośród wymienionych najsilniej oddziałują na wysoki poziom motywacji u ich dzieci do uczęszczania na lekcje w szkole i zdalne. Zadaniem osób badanych było zaznaczenie maksymalnie trzech odpowiedzi na każde z pytań oddzielnie, umożliwiono też wpisanie własnej pozycji w rubryce „inne”. W przypadku lekcji w szkole zaproponowano następujące opcje wyboru: wysokie oceny (6\%), obawa przed uzyskaniem niskich ocen (6\%), wsparcie rodziców (22\%), wsparcie nauczycieli (50\%), chęć zdobywania wiedzy i rozwoju (24\%), możliwość spędzania czasu poza domem (44\%), bezpośredni kontakt z rówieśnikami (96\%), atrakcyjność lekcji (54\%); jedna $\mathrm{z}$ ankietowanych osób jako czynnik motywujący wskazała bezpośredni kontakt $z$ nauczycielami (2\%). W celu rozpoznania elementów wpływających na wysoki stopień motywacji do uczestnictwa w lekcjach zdalnych w kwestionariuszu zamieszczono również kilka wariantów z możliwością dopisania własnego, dzięki czemu uzyskano pięć dodatkowych opcji: 1) nic (10\%); 2) brak konieczności starania się, np. starannego prowadzenia zeszytu $(2 \%) ; 3)$ możliwość spędzania więcej czasu przed komputerem $(2 \%)$; 4) więcej snu (2\%) oraz 5) możliwość uczenia się w wygodnych warunkach (2\%). Ponadto kwestionariusz zawierał następujące odpowiedzi do wyboru: wysokie oceny (18\%), obawa przed uzyskaniem niskich ocen (18\%), wsparcie rodziców (60\%), wsparcie nauczycieli (28\%), chęć zdobywania wiedzy i rozwijania się (24\%), brak bezpośredniego 
kontaktu z rówieśnikami (6\%), możliwość spędzania czasu w domu (44\%) oraz atrakcyjność lekcji (38\%).

W związku z powyższym do trzech czynników spośród zaproponowanych, najsilniej oddziałujących na wysoki poziom motywacji do uczęszczania na lekcje w szkole, zalicza się: bezpośredni kontakt z rówieśnikami, atrakcyjność lekcji oraz wsparcie nauczycieli. Nawiązując do części pracy opisującej specyfikę wieku wczesnoszkolnego oraz edukacji w tym okresie, można zauważyć powiązanie pomiędzy charakterystycznymi dla tego wieku potrzebami (np. uatrakcyjnianie lekcji m.in. przez eksperymentowanie, stosowanie różnych metod ułatwiających rozumienie) oraz zachodzącymi zmianami, wiążącymi się ze zmianą otoczenia, wejściem w świat szkolny i rówieśniczy, a poziomem motywacji do uczestnictwa w lekcjach w szkole.

Podsumowując zebrane dane, można stwierdzić, iż okres pandemii nie sprzyja kształtowaniu motywacji wśród dzieci w wieku wczesnoszkolnym. Sytuacja, w której uczniowie muszą korzystać z edukacji zdalnej zamiast uczęszczać do szkoły, odbiera im wiele możliwości oraz utrudnia zaspokajanie potrzeb charakterystycznych dla tego etapu rozwojowego. Edukacja w trybie zdalnym jest korzystna $z$ wielu przyczyn, jednakże wyższy poziom motywacji do działania w różnych sferach życia dziecka się uwidacznia, gdy dzieci uczęszczają na lekcje w szkole.

\section{Bibliografia}

Adamek, I. (1997). Podstawy edukacji wczesnoszkolnej. Kraków: Impuls.

Bee, H. (2004). Psychologia rozwoju człowieka. Przeł. A. Wojciechowski. Poznań: Zysk i S-ka.

Erikson, E. H. (1997), Dzieciństwo i spoteczeństwo. Przeł. P. Hejmej. Poznań: Rebis.

Franken, R. E. (2005). Psychologia motywacji. Przeł. M. Przylipiak. Gdańsk: GWP.

Gerrig, R. J., Zimbardo, P. G. (2012). Psychologia $i$ życie. Przeł. J. Radzicki i in. Wyd. 3 nowe, 4 dodr. Warszawa: PWN.

Grabania, M. Ł., Ślusarczyk, M. (2017). E-learning wspótczesnym narzędziem nauczania. „Szybkobieżne Pojazdy Gąsienicowe", 4, nr 46, s. 33-40.

Koludo, A. (2020). Strategie kształcenia na odległość. W: J. Pyżalski (red.), Edukacja w czasach pandemii wirusa COVID-19. Z dystansem o tym, co robimy obecnie jako nauczyciele. Warszawa: EduAkcja, s. 43-50.

Kordziński, J. (2007) Motywacja — tajemnica szkolnych sukcesów. Fak wzbudzić w uczniach pragnienie uczenia się - poradnik nauczyciela. Warszawa: Verlag Dashöfer.

Murawska, B. (2014). Edukacja wczesnoszkolna. Wiek 5/6-8/9 lat. „Niezbędnik Dobrego Nauczyciela", 3. Warszawa: Instytut Badań Edukacyjnych.

Plebańska, M. (2011). E-learning. Tajniki edukacji na odlegtość. Warszawa: C. H. Beck.

Stefańska-Klar, R. (2000). Późne dziecinstwo. Młodszy wiek szkolny. W: B. Harwas-Napierała, J. Trempała (red.), Psychologia rozwoju człowieka. Charakterystyka okresów życia człowieka. T. 2. Warszawa: PWN, s. 130-162.

Sendecka, Z. (2017). Ksztatcenie myślenia naukowego uczniów we wczesnej edukacji przyrodniczej. Warszawa: Ośrodek Rozwoju Edukacji. 
Walter, N. (2020). Mamy (za)duży wybór — jak nie zgubić się wśród narzędzi cyfrowych?. W: J. Pyżalski (red.), Edukacja w czasach pandemii wirusa COVID-19. Z dystansem o tym, co robimy obecnie jako nauczyciele. Warszawa: EduAkcja, s. 51-58.

Woźniak, J. (2009). E-learning w biznesie i edukacji. Warszawa: Wyd. Akademickie i Profesjonalne.

Zimbardo, P. G. (1999). Psychologia $i$ życie. Przeł. E. Czerniawska i in. Warszawa: PWN.

Zimbardo, P. G., Johnson, R. L., McCann, V. (2017). Psychologia - kluczowe koncepcje. [T. 2:] Motywacja i uczenie się. Przeł. M. Guzowska-Dąbrowska, J. Radzicki. Warszawa: PWN.

Rozporządzenie Ministra Edukacji Narodowej z dnia 14 lutego 2017 r. w sprawie podstawy programowej wychowania przedszkolnego oraz podstawy programowej kształcenia ogólnego dla szkoły podstawowej, w tym dla uczniów z niepełnosprawnością intelektualną w stopniu umiarkowanym lub znacznym, kształcenia ogólnego dla branżowej szkoły I stopnia, kształcenia ogólnego dla szkoły specjalnej przysposabiającej do pracy oraz kształcenia ogólnego dla szkoły policealnej. DzU, 2017, poz. 365. 